\title{
'Survival of the fittest plastics' : een evolutie die we uitlokken of ondergaan
}

Citation for published version (APA):

De Wildeman, S. M. A. (2015). 'Survival of the fittest plastics' : een evolutie die we uitlokken of ondergaan. Maastricht University. https://doi.org/10.26481/spe.20150911sw

Document status and date:

Published: 11/09/2015

DOI:

10.26481/spe.20150911sw

Document Version:

Publisher's PDF, also known as Version of record

\section{Please check the document version of this publication:}

- A submitted manuscript is the version of the article upon submission and before peer-review. There can be important differences between the submitted version and the official published version of record.

People interested in the research are advised to contact the author for the final version of the publication, or visit the DOI to the publisher's website.

- The final author version and the galley proof are versions of the publication after peer review.

- The final published version features the final layout of the paper including the volume, issue and page numbers.

Link to publication

\footnotetext{
General rights rights.

- You may freely distribute the URL identifying the publication in the public portal. please follow below link for the End User Agreement:

www.umlib.nl/taverne-license

Take down policy

If you believe that this document breaches copyright please contact us at:

repository@maastrichtuniversity.nl

providing details and we will investigate your claim.
}

Copyright and moral rights for the publications made accessible in the public portal are retained by the authors and/or other copyright owners and it is a condition of accessing publications that users recognise and abide by the legal requirements associated with these

- Users may download and print one copy of any publication from the public portal for the purpose of private study or research.

- You may not further distribute the material or use it for any profit-making activity or commercial gain

If the publication is distributed under the terms of Article $25 \mathrm{fa}$ of the Dutch Copyright Act, indicated by the "Taverne" license above, 
Prof. dr. ir. Stefaan M.A. De Wildeman Faculty of Humanities and Sciences

\section{'Survival of the fittest plastics' Een evolutie die we uitlokken of ondergaan}


Inauguration

Prof. dr. ir. Stefaan M.A. De Wildeman

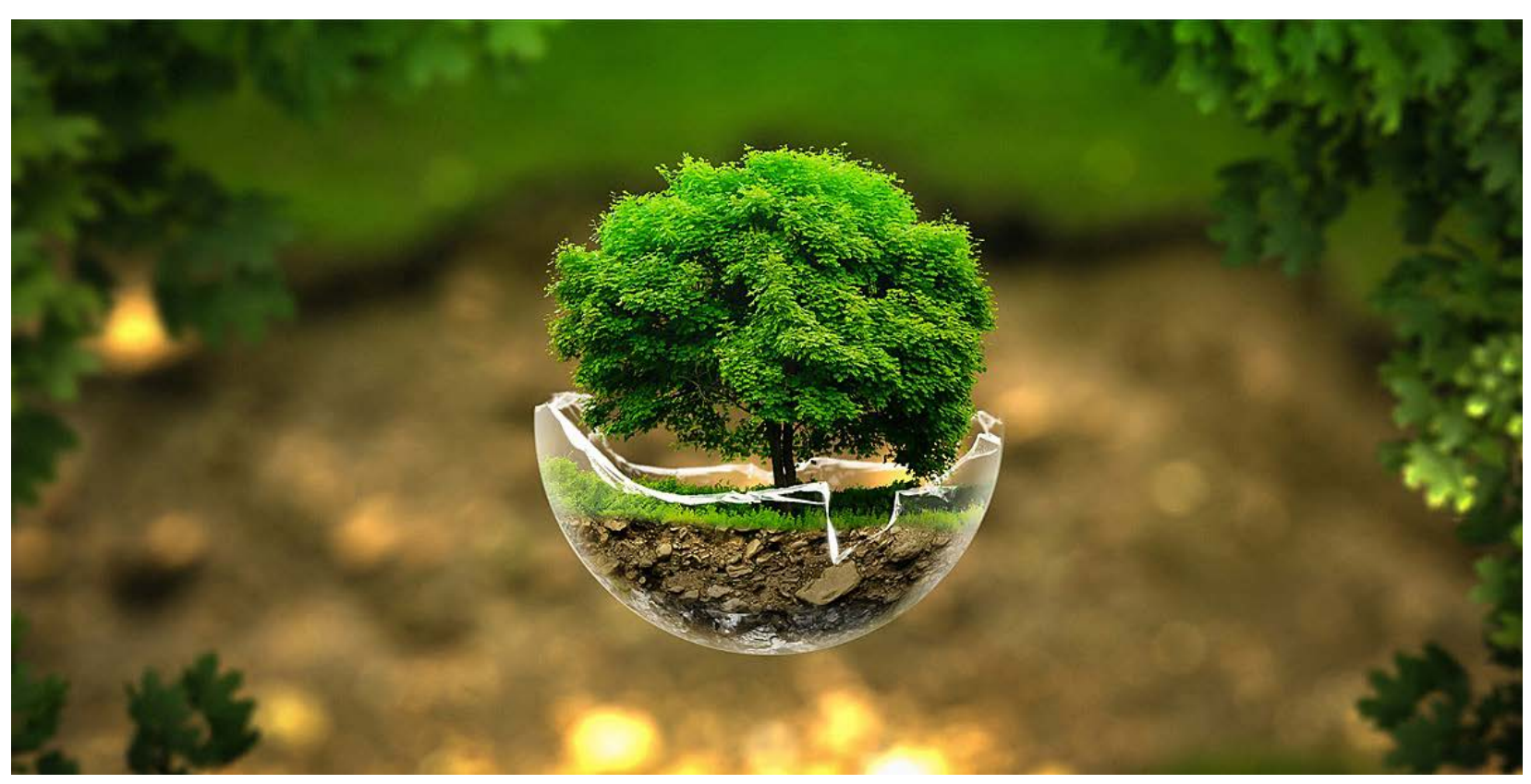

Picture reproduced from http://change.news/

'Survival of the fittest plastics'

Een evolutie die we uitlokken of ondergaan

Maastricht, University Aula, 11 september 2015 
Ladies and gentlemen, dear rector magnificus, dear managerial college, dear deans of current and former legislation, dear managerial board, dear collegues, dear family, "beste nageslacht" or so-called next-generation present in the room, dear friends and all who are listening today or tomorrow. I really have been looking forward to this day - this moment - to make it a symbolic milestone on our way together - transitioning from our fossil reality into a renewable world - a journey that seems intriguing and necessary at the same time. And with joy and passion, I have prepared the following lecture for us all. 


\section{Introduction}

In den beginne was er niks - ook geen plastics.

At the origin of times, there was nothing - even no plastics.

Now, they are everywhere. "Plastics are everywhere."

This subtitle was the appetizer for the first Microplastics Symposium in the world, organized by the Nova Institute in Cologne, 1st of July last year.

Indeed, plastics - the easy-going and populistic name for kunststoffen - have entered our lives from many angles. In the beginning they were the cheap alternatives for our natural products. Handy but a bit fake. After almost one century since their very first arrival in our society, they have been perfected and diversified. A whole plastic science and industry has been developed. And now, they seem to have become superior to any natural product they ever substituted. Though, their superiority has its limits. Because they do not only enter our lives anymore from the products we buy. We also get them back, readily unknown and invisible, from Nature. Because that's what it is nowadays: we get some plastics back from Nature. For instance, in our food. Our appetizing plate with mussels contains about 90 small plastic parts. Bio-honey, contains small plastic parts. Our bodies contain small plastic parts. You hardly see them - today I do not say they are always toxic - but they are there.

\section{Microplastics}

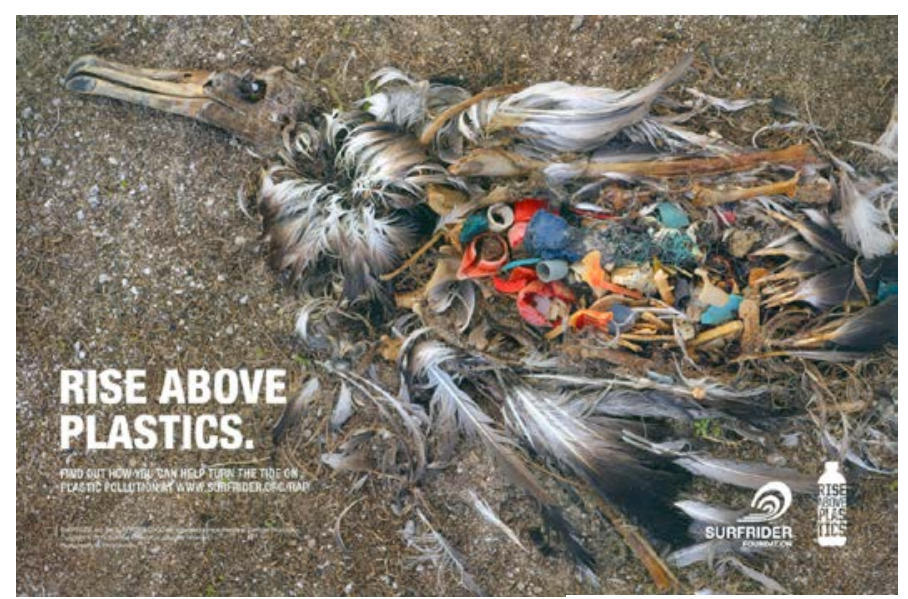

Maastricht University im Lesming 
Plastics are probably not only everywhere, they are maybe underway to become eternal - kind of. Suppose people would not be eternal, than most of our currently used plastics might be. No idea how many of those "micro's" there will be in a few decades from now. But their population is growing - every day. Because our wide oceans on earth, host the so-called plastic soup. Not one soup, at least five already.

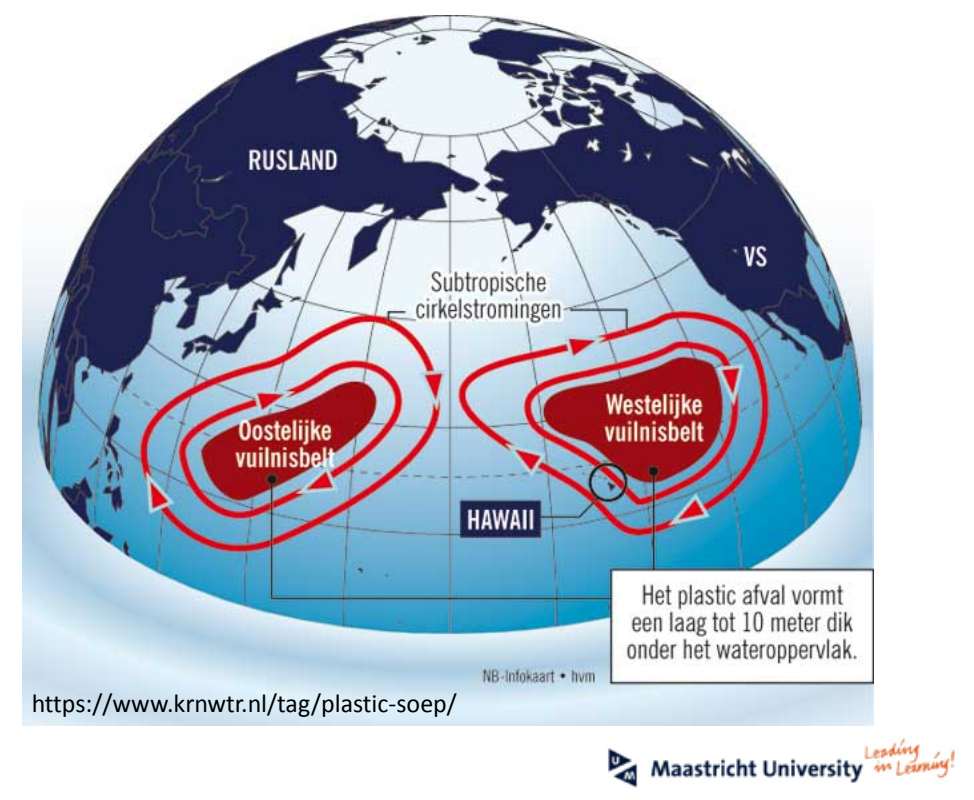

And they are moving slowly, as big artificial islands. People are modeling their travelings around the globe. We might organize exclusive boat tours to visit and watch them, announced: "Visible left-overs -visible trash- of the fossil era". And they are ticking time bombs. We understand that sometimes they carry toxic viruses and bacteria, as if they were a living infecting uncontrollable plastic monster. So how to get control back?

Fishing out the soups is not a bad idea, it is brave! Although it is probably only a partial solution. The majority of trash is partially attacked by micro-organisms or overgrown by aquatic fauna and flora, it gains density, and sinks to the bottom. Difficult to fish at the bottom. Even more, nobody on earth, ever finds the energy, to reverse this wild uncontrollable dissipation machinery we created ourselves. The boost in micro-plastics sciences started only some five years ago. And the message came fast and impactful: suppose there is some evel in microplastics, the evel might have happened. What 
numbers are we talking about? Of the current 300 MT yearly plastics production, about $3 \%$ or $10 \mathrm{MT}$ are leaking into the environment. For the fast brains in the public: $30 \mathrm{kT}$ per day. Ladies and gentlemen, I'm sorry: we seem a bit out of control.

Still, I am standing here. I even smile. And I know why. Let's calm down. And let me say: the glass with ocean water is half full. Because there might be some light in partially redesigning our plastics. For instance to become degradable where and when that is needed in the application. At least, it would target the source, instead of fishing soups out of oceans afterwards. But speaking about sources... the plastics industry has its fundaments in the overwhelming flood of fossil resources: coal, oil, gas, shale gas... All plastics in this room most likely are purely fossil-based.

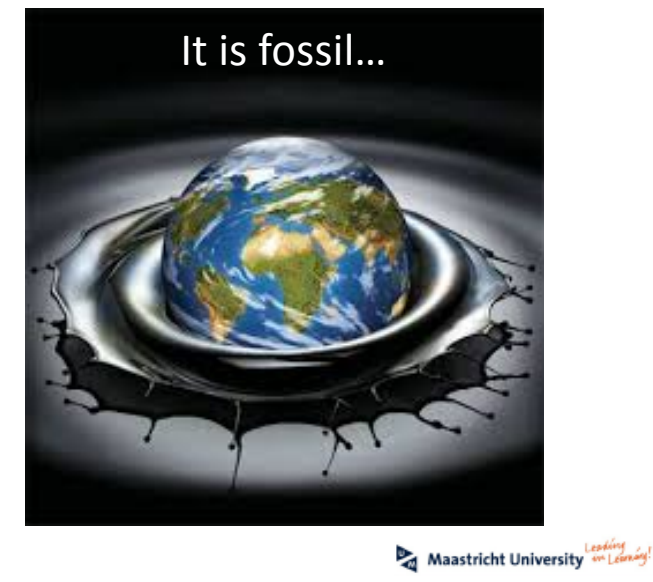

We did not get any better last century. We did not know any better. There was the end of the second world-war, and there was the possibility to re-build our world - stronger than ever, and with plastics as one of the driving innovations. So we did. Those were the times, when two chemical plants per year were built at the Chemelot site, to become one of the biggest chemical industrial sites in Europe. In front of me are the generations that had the fastest development in luxury goods and products ever. On the frontrow is already the next generation - they will be hampered to grow further. That's not bad because nothing grows forever. We all know that - although it's hard to admit if your own luxury position depends on it and the future is not clear. It requires trust. And we do not per se live in a world of trust. But luckily you don't need growth to be happy. Unlimited growth only exists in the brains of people. And the eagerness to grow unlimited, the 
credo of capitalism, I dare to call a sickness of the human brains. It is virtual. In almost 4 billion years of Life evolution on earth, there has not been any species that had the right to grow without any limits. If we think we can do it: it means that we are at least an exception - an excess - in natural history. And I know what Nature might do with excesses: they are eliminated. Homo sapiens: come back to reality please, or disapear. But back to business with another fact about plastics. Remember the 90 micro-particles in my plate full of mussels. They have traveled to reach me. And far !

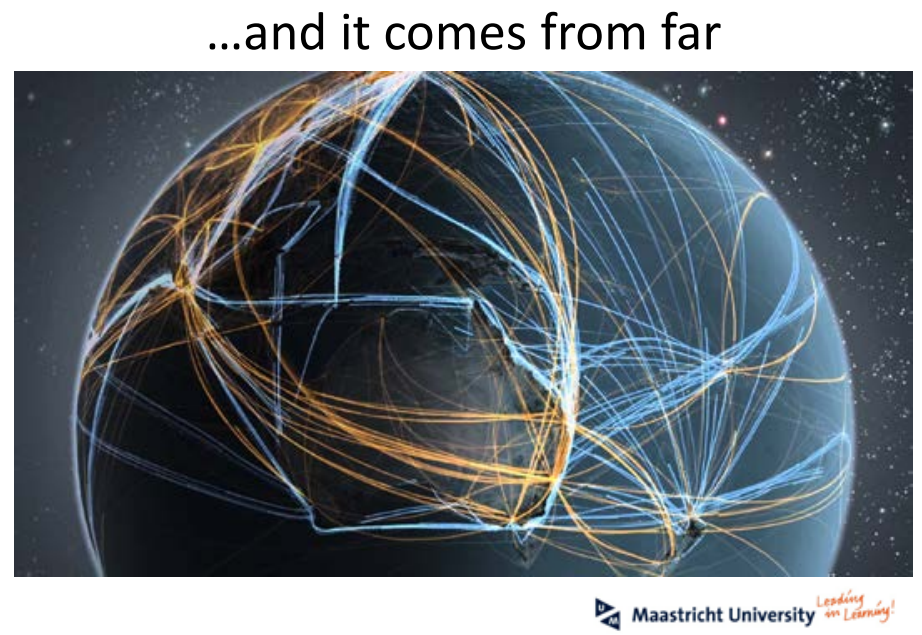

Their carbon is derived from fossil resources exploited somewhere in the Mid-East - for instance - most likely not in Europe. From there, they got transported to get refined, cracked, purified, chemically modified and polymerized - most likely on different continents with worldwide logistics. The last part of their travel scheme from application to the mussles in my plate, is meanwhile understood. Today, statistics are still rare about the average distance plastics travel... to finally arrive at places where they were even not awaited, or welcomed. Plastics are not only everywhere, they have their own travel agency.

But than, there is something more with plastics. For me it is the most fenomenal aspect of all. We got used to them. Too used. They are cheap. And they never really speak to us - so far. For end-consumers, plastics have no name, no face, no personality, no soul, no spirit. We hardly think about them. We rip them off from our food in seconds in the 
morning. We live in a kind of non-communicative symbiosis. The more specialty plastics in our lives, are even hidden - in our iphones, under the hoods of our cars. We cánnot see them. We hardly know their existence or their roles. One of the reasons for this is that plastics most often exist in an ultimate service role. We do not buy a ballpen because there is some plastic around, but because we want to write. Plastics are only the add-on, at most they are the invisible enablers. They enable functionality, but are not named themselves at the stage of the end-consumer. They lead many shows, but always from the hidden backstage, and in complete silence. Behind their development and existence however, is a whole B2B (business to business) world, with testing schemes, registrations, and many performance parameters. But for the end-consumer, after all is said and done, they stay anonymous. They miss personality. They miss charm. They miss warmth. They can be as good as you explain to the public, but they remain just damn plastics, and nothing more. Plastic fantastic.

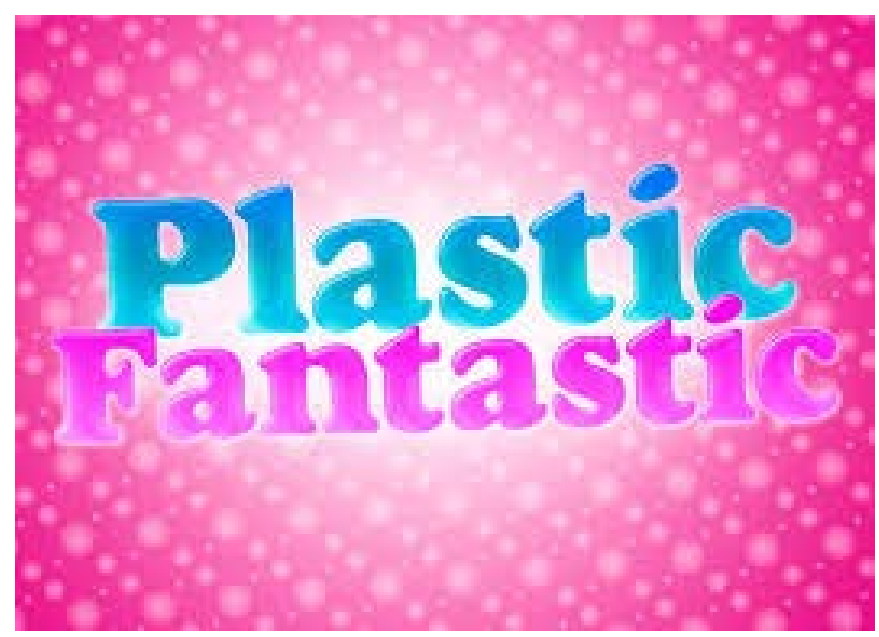

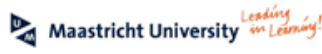


And if anything more, the few seconds we think about them, they associate with old chemistry, maybe dirty or dangerous, toxic, hopefully happening somewhere far away from our lives.

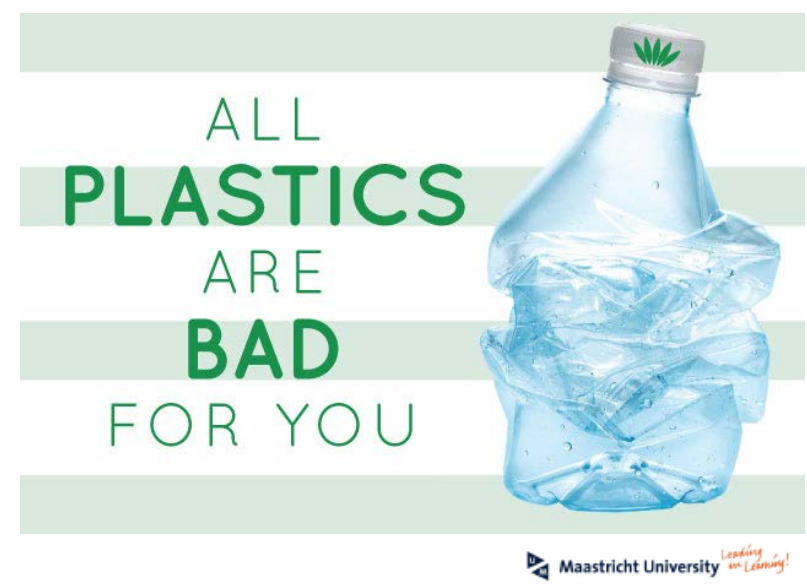

It also takes nothing to throw plastics away. Every room has a bin - I would say. I would call plastics in everyday life "ambassadors of our linear economy": "easy gain - easy dump". Don't think - let it go! By the way, it is convenient after all, and there is hardly any other offering to find. Over $200 \mathrm{~kg}$ of plastics are consumed every year per capita in the Benelux. We zijn grootverbruikers! And we all are captured in the system. No other offerings, apparently.

\section{Linear versus circular economy}

\section{LINEAR}

CIRCULAR

\begin{tabular}{|c|c|c|}
\hline Driver & Grow & Sustain \\
\hline Products are... & owned & used \\
\hline Resources & Easy gain, easy dump & "there is no waste" \\
\hline \multirow[t]{2}{*}{ Consciousness level } & $\begin{array}{l}\text { LOW } \\
\text { Infant, instinctive, evident }\end{array}$ & $\begin{array}{c}\text { HIGHER } \\
\text { Mature, proactive, } \\
\text { thoughtful }\end{array}$ \\
\hline & $\begin{array}{l}\text { "we receive" } \\
\text { passive }\end{array}$ & $\begin{array}{l}\text { "we guard" } \\
\text { active }\end{array}$ \\
\hline Cornerstone & $\begin{array}{l}\text { Economy of scale } \\
\text { Centralized }\end{array}$ & $\begin{array}{l}\text { Diversification } \\
\text { Delocalized }\end{array}$ \\
\hline
\end{tabular}

Maastricht University in Leaning! 
I can shortly end this long introduction about the 3 plastics phenomena I described and collected today for us: microplastics, worldwide shipment of fossil resources, and the image of plastics in the broad public.

In my opinion, those 3 phenomena shed a very strange light upon this sunny 11th september 2015. I would not be surprised if, without determined action, without industrial leadership, without academic driving force, without the overlap between both following rules that we still have to invent, this nine eleven hits us much harder than the other one - unluckily. The plastics problem as depicted has reached the top-5 of big challenges to continue our life on earth in the long run. Planet Earth keeps readily quiet at this moment. We can doubt about tomorrow. The final conclusion has not yet been communicated to us. There are parallels with the way we get information about climate change. Apparently, our "unlimited eagerness to unlimited growth" has created time bombs that will be hard to overcome, and probably makes us unlimited vulnerable in the end. Predicted growth in world population and industrial production, will not help to calm down.

But still, the next generation is in the room, and we have to formulate our answers - the sooner the better. I look into their eyes, and I am triggered to find solutions. I am even sure we will find solutions. They might be rather unexpected, and very unconventional a way of living that is in the genes of this University. How this is happening already in our laboratories, in preparation of new insights, new products, new employment, and local preparation for a new future, is what I am eager to tell you in the upcoming half hour. Finally, here we go! 


\section{Corpus}

First - let's set the scene and connect the plastic theme to some supportive trends that we observe in society.

Walmart is my first example: they have started to document parts of their product spectrum with carbon footprint: $\mathrm{kg}$ carbon dioxide produced for the product as you can buy it. Well, we are missing some daily information in that respect. Economic figures are written and discussed in newspapers, journals, columns, on radio's, television and a dozen of other media. Daily, hourly. But do you think I can find somewhere the carbon footprint of the shoes on my feet? Who knows how many kilometers I can ride my car equaling the carbon footprint of a small 250-gram T-bone steak? Who knows how much gram carbon dioxide you produce while sitting down and listening with slightly elevated hartbeat? But that the Chinese economy slowed down another 0,1\% - we know before we reach home tonight. Millions of people know before they reach home tonight. But why nothing on ecology? Is the oxygen I breathe not important enough? You know I can hardly survive for 3 minutes without? What a virtual reality we are living in. So Walmart you started a great thing. Thank you. We will make more of this.

My next example is BMWi, the ecological sub-brand of BMW. Their small car - the i3 costs about double the price of an equivalent small-sized car, while it rides slightly over hundred kilometer in one battery cycle. A battery with sixhunderd cycles only - though there is eight years guaranteed pleasure. Double price, 20 percent action radius. Does it sell? Production cannot follow. What I especially like about this product, is the fact that you think about its end-of-life while you stand next to a brand new one in the showroom. That's the extra eco-dimension: it lets you think ! It tells you the story from cradle to grave in 1 second. Chapeau.

A completely other evolution happens on the road to a new economic network - de deel-economie - where the employee him or herself is in the center, maximizing own talents and driving force at the benefit of several complementary employers in innovative 
eco-systems around. Old rules of how we develop, produce, market and recycle our goods - so also plastics - could heavily be impacted as a consequence. Brightlands Chemelot Campus is developing towards such a hub that is pioneering and setting great steps in this respect. The institutes AMIBM (Aachen Maastricht Institute for Biobased Materials), BMC (Brightlands Materials Center), and InSciTe (Institute for Science and Technology) evoke great expectation to let extra-ordinary innovations happen. Many open campuses are under development nowadays, each with own identities taking specific roles in society. And talking about those hubs: it is not about being the best hub, because in a more delocalized bio-economy, we will need local hubs with their own complementary role every few 100 kilometer - so I am not convinced of real competitive effects. In contrast, open innovation will be the game to play. This in itself links to survival of the fittest.

\title{
On the origin of Open Innovation
}

\author{
"In the long history of Life on earth, \\ those who learned to collaborate \\ and improvise most effectively have \\ prevailed."
}

-Charles Darwin

Another shift in my short list of examples: the Do-It-Yourself wave. We see people in small cooperations starting to build their own houses with very unconventional but preferred architectural styles. They are beyond the hype stage. In the US energy markets, private people have started to grow algae in their gardens, to disconnect their energy needs from badly documented existing energy infrastructure, and simply from economic dependence. They do not longer debate if nuclear energy is good or bad. They just say "thank you - I do not need you anymore". Why would we not enable to make plastics from our own gardens? Do-it-yourself... 
These few observations give us sufficient support to further define our plan of action: how to mobilize the forces of this university and all her partners towards biobased innovation?

Unconventional, was the word I used.

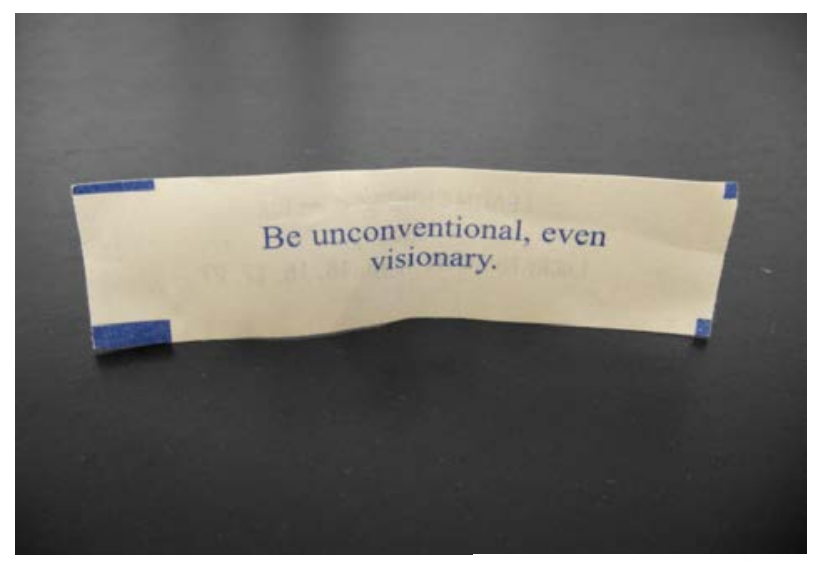

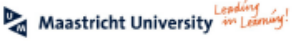

Is there anything to play unconventionally? I know something. There are dogma's out in the industrial world, so let's see how fit they are for survival! A dogma I interprete as something you will be criticized for, if you start to criticize it. The perfect situation for this university to start. 
Dogma number one. If you do anything, make sure you can guarantee that it will be big. Go big! Or do nothing.

Well, first of all, I am not sure if it will be big. There is only one certainty: it will be very small in the beginning. And it might be that we decide that small is beautiful. And only after that, it might become bigger, or even big, as you wanted. If this path is not pleasing, you might not qualify for biobased innovation. Simple as that. But... not too simple to have become the main hurdle towards innovation in many established research organizations and investment funds.
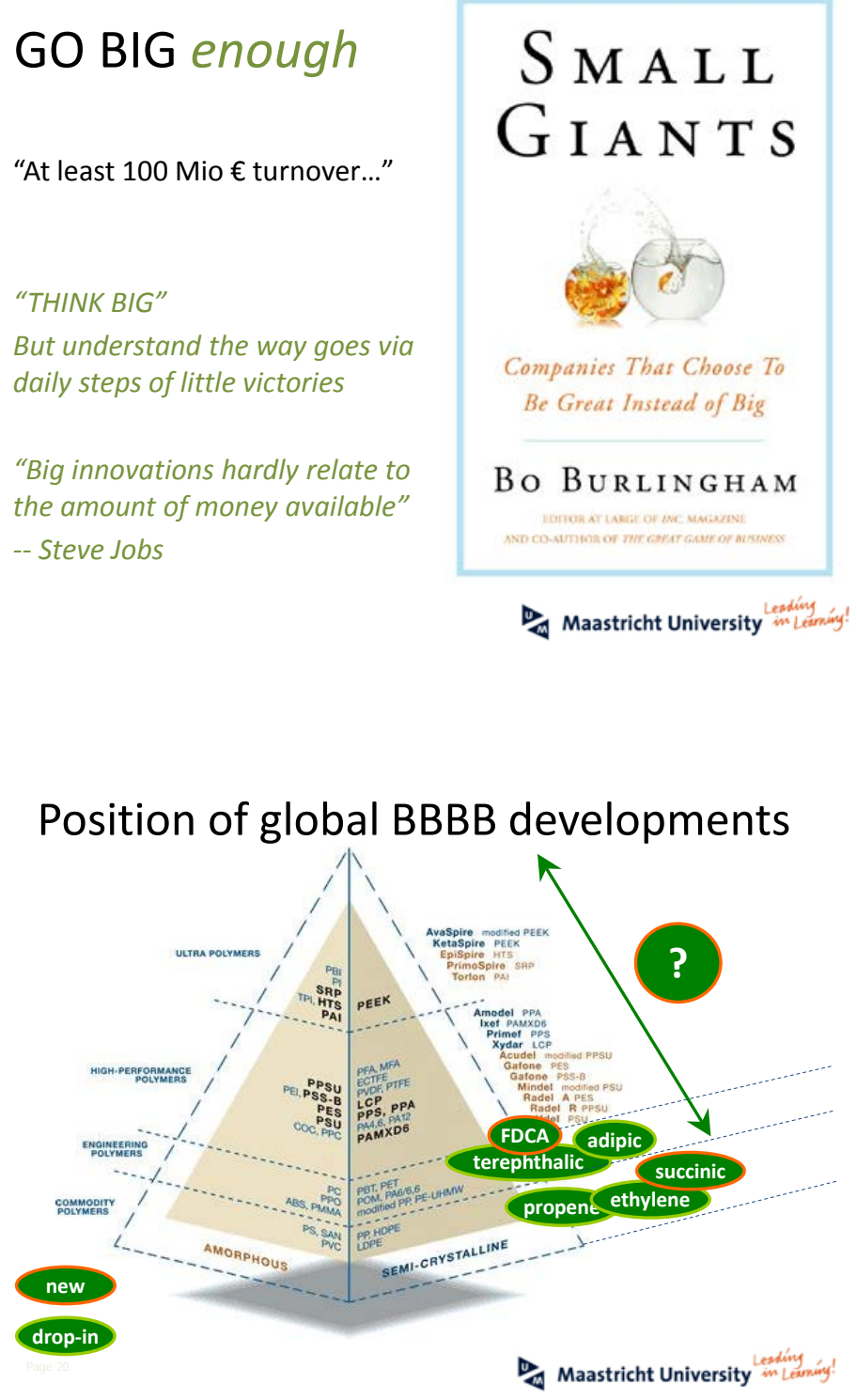
Dogma number two. Go fast.

Confer dogma number one. Small to bigger, bigger to big,... needs time. But earlier started, based on vision and endurance: earlier results. You know: you can go slow if you doubt too long how to go fast. Time is money. Tomorrow, time might not be money at the first place - time might be scarce.

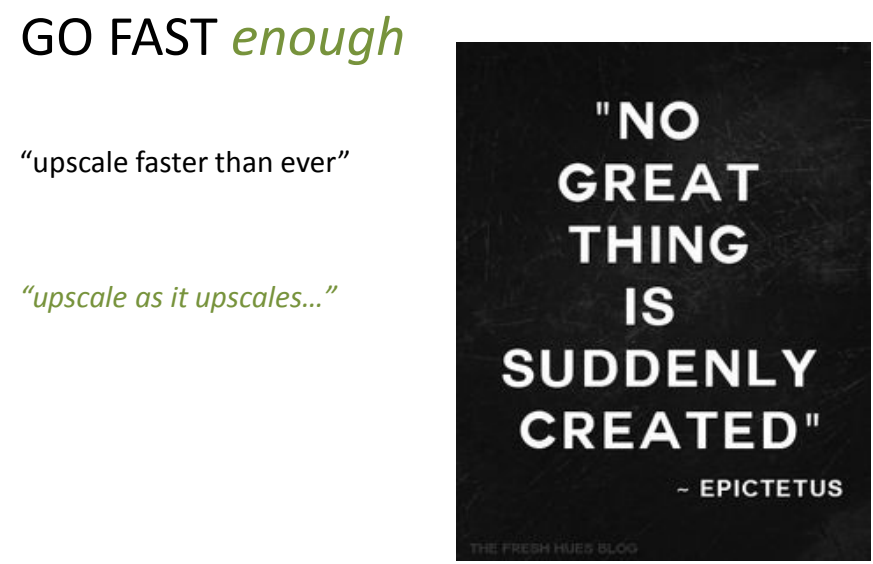

$\checkmark$ Maastricht University "mestiny 
Dogma number three. Do it global. Go for nothing less than global please!

\author{
And GLOBAL/y impactful, but local \\ "boost business" \\ "respect the rules of our planet" \\ Sun shines on every square meter \\ Local for local, serving global well-being
}

\title{
Dos Maastricht University
}

\section{(Also see English translated DOGMA's as appendix)}

Dit is het moment der Nederlandse taal. Welkom aanwezigen. Ik had jullie door de plastic hetze van de afgelopen minuten nog niet eens in het Nederlands kunnen begroeten. En gezien we op lokale bodem staan, met lokale agro-bronnen buiten op de akkers omheen Maastricht en omstreken, heb ik eigenlijk weinig reden om Engels te praten vandaag, laat staan naar de andere kant van de wereld te reizen, toch? Zijn de mensen daar slimmer misschien? Zijn de bronnen daar beter misschien? Hoeven we geen tewerkstelling op eigen bodem misschien? Zijn we uitgedacht hoe dat voor elkaar te krijgen misschien? Zouden we niet lokale kunststoffen kunnen bedenken misschien, vanop onze eigen akkers, met eigen mensen, voor eigen afzet, met eigen verantwoording? Precies zoals ik de appel van de boom in mijn tuin sta te schudden? Welk ander deel van de wereld heb ik eigenlijk zo broodnodig? OK, culturele en technologische uitwisseling, verrijking, leren van elkaar. Maar toch geen goederen en grondstoffen verschepen van de ene kant naar de andere kant? Ik stel alleen vast dat de mens het enige species op aarde is, dat zich vrijuit veroorlooft goederen en zichzelf zonder enige limiet te transporteren, zonder dat hij daarzelf maar bij benadering de ecofootprint van kent. De natuur heeft in elk geval nooit haar voedsel en energie van de ene kant naar de andere kant getransporteerd op "onze" manier. En de zon met alle energie die we - strikt gezien - nodig hebben komt elk etmaal netjes voorbij: dat is precies de reden waarom de aarde draait. Dan hoeven wij zelf toch niet meer extra te draaien en 
onze zo onbegrepen planeet tomeloos uit te dagen? De wereld mijn dorp...? De wereld mijn vuilnisbelt, net omdat mijn dorp niet langer de wereld is. Voor de wereld mijn dorp, zijn we nog lang niet klaar. Zullen wij ons aanpassen aan de limieten van onze werkelijkheid? Of zullen we onze eigen onbegrepen oorsprong vragen zich aan te passen aan ons? Hebben wij het recht ruim 4 miljard jaar in vraag te stellen? Omdat we het lampje in huis willen aanzetten wanneer wij dat willen? Als ik kijk hoe infantiel onze plastics zijn tegenover alle natuurlijke materialen die we kennen, dan neig ik naar enige vorm van nederigheid. Het spel van de wel 20 verschillende soorten polyamide strengen die uit het achterlijf van de spin komen om haar web te bouwen, overtreffen alle synthetische polymeren die ik ooit bij elkaar heb gezien. We hebben nog wel wat tijd nodig om dat na te maken en er zinnig profijt uit te halen. De vinding gisteren uit de universiteit Gent, dat er een nieuwe doodlopende tak is ontdekt in de stamboom van de mens, duidt er weer op dat ook de natuur faalpogingen heeft moeten ondernemen om tot deze mate van perfectie en adaptatie te komen. Of dacht je dat onze plastics uitontwikkeld waren, en klaar zijn voor wat op ons afkomt? 
Dogma nummer vier: Geen risico's !

Geen enkele innovatie komt zonder enig risico. We moeten risico's weer haalbaar maken.

\section{Without moderated RISK}

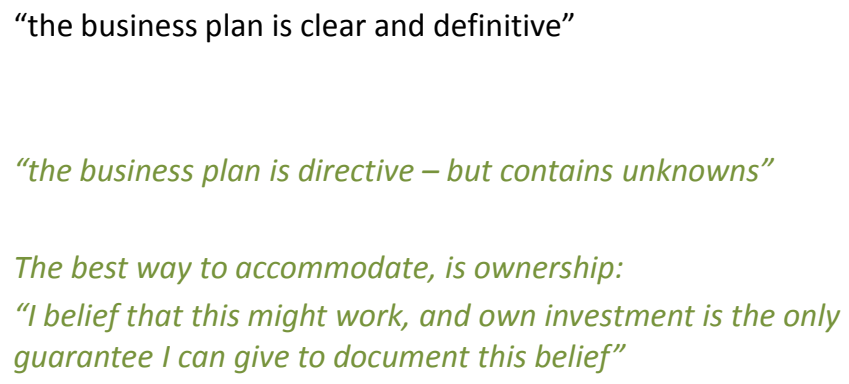

"the business plan is clear and definitive"

"the business plan is directive - but contains unknowns"

The best way to accommodate, is ownership:

"I belief that this might work, and own investment is the only guarantee I can give to document this belief"

$\checkmark 4$ Maastricht University im Lemning!

Dogma nummer vijf: met oneindige groei !

Niets groeit oneindig in een eindig systeem. Oneindigheid is een projectie van onze eigen hersenen, dat misschien of wellicht bestaat in een andere wereld, maar niet binnen de fysieke realiteit van onze planeet zoals we die vandaag nog maar begrijpen.

\section{With eontinued moderated GROWTH}

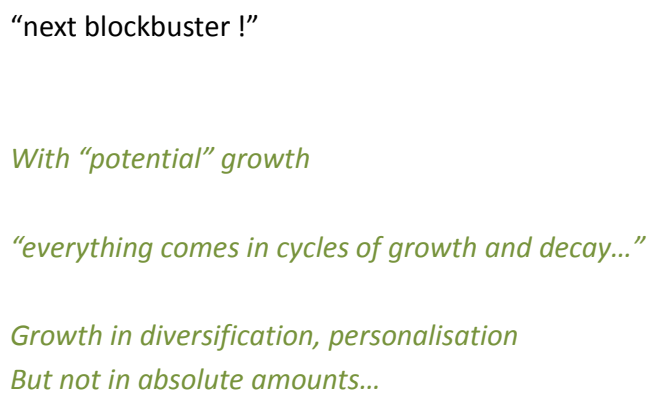


Dogma nummer zes: out-performance ! Is de enige reden om te innoveren enkel maar als het beter is dan al hetgene we totnogtoe hadden, in cijfers en metingen? Ook als dat ten koste gaat van "oneindige" duurzaamheid? Is hetgeen we hebben dan trouwens zo goed...? Het olympisch streven en de prestatie-drang van onze hersenen, is op zijn plaats tijdens de Olympische Spelen en in de sportclub, maar toch niet op elk productje uit ons dagelijks leven. Van overdreven perfectie kan je sterven.

\section{Our brains go olympic...}

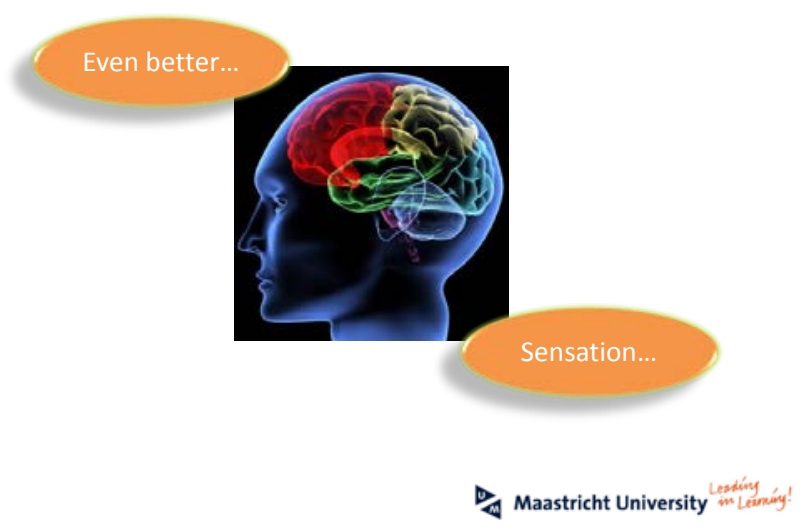

Dogma nummer zeven: standardizeren - in natuurlijke termen vertaald: kloneren. De reden waarom het leven op aarde nog bestaat, is voortgevloeid uit het feit dat leven zich nagenoeg NIET kloneert. Overleven en aanpassen vloeit voort uit diversificatie, gevolgd door selectie. Standaardiseren en consolideren kan in de natuur als quasi-fout aangezien worden.

Standardized...

"ASTM tested, exact copies (in natural terms: clones)..."

"Survival of the fittest"...

Standardization undermines the capability to adapt to change

So does consolidation (only 5 plastics in the end ?)

So does economy of scale (invested assets)

If the Sustainability Revolution is underway, our "unlimited

economic system" makes us "unlimited vulnerable" for extinction

$\checkmark 4$ Maastricht University "m Leming? 
Verdere Slides:

Changing winds in global polymer world

Changing winds in global polymer world...

XLTerra

"Polymers for the 21st Century:

Inventing for the Better Tomorrow"

There is a belief that growing and greening

the 300 MioT of nowadays plastics

will not effectuate only via "drop-in",

but game-changing new biobased building blocks

will enter and rebalance the scene

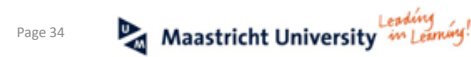

Everything we do,

we believe in challenging

the Status Quo

(quoted from XLTerra, July 2012)

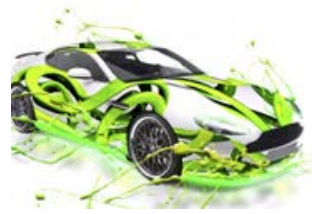

Page 35 Mastricht University "unding Leming!

Our whole industry and trust is based on a tiny black spot in a geological timeframe?

Who explains the logic...

... of sticking to our current set of fossil building blocks, while completely switching our resources from fossil to renewable?

In other words...

.... are the blocks that contribute to ultimate sustainability,

per definition those that arose

from a non-sustainable era? 
Biobased building blocks have large potential...

... which biobased blocks have large potential ?

"... which Bio-based building blocks have large potential ?"

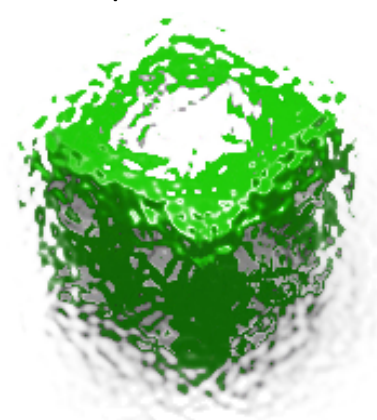

Page 43 Maastricht University Lendiny Leiming!

The very different "nature" of fossil and renewable resources

Functionality in materials

fossils versus Nature's diversity

Fossils

- 2 dominant atoms (C, H)

- Linear chains / benzene ring

- No chirality

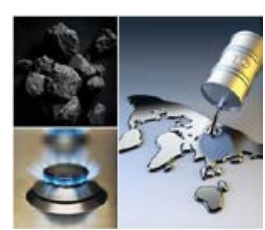

Nature's diversity

- 4 dominant atoms (C, H, O, N)

- Variety of structures

- Chirality dominates Life

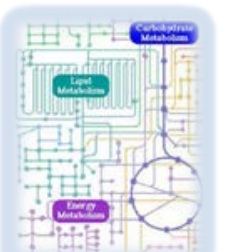

Page 44 Maastricht University 'menting Lemming! 
Drop-in versus newBBBB - different business dynamics

\section{Drop-in versus newBBBB - business dynamics}

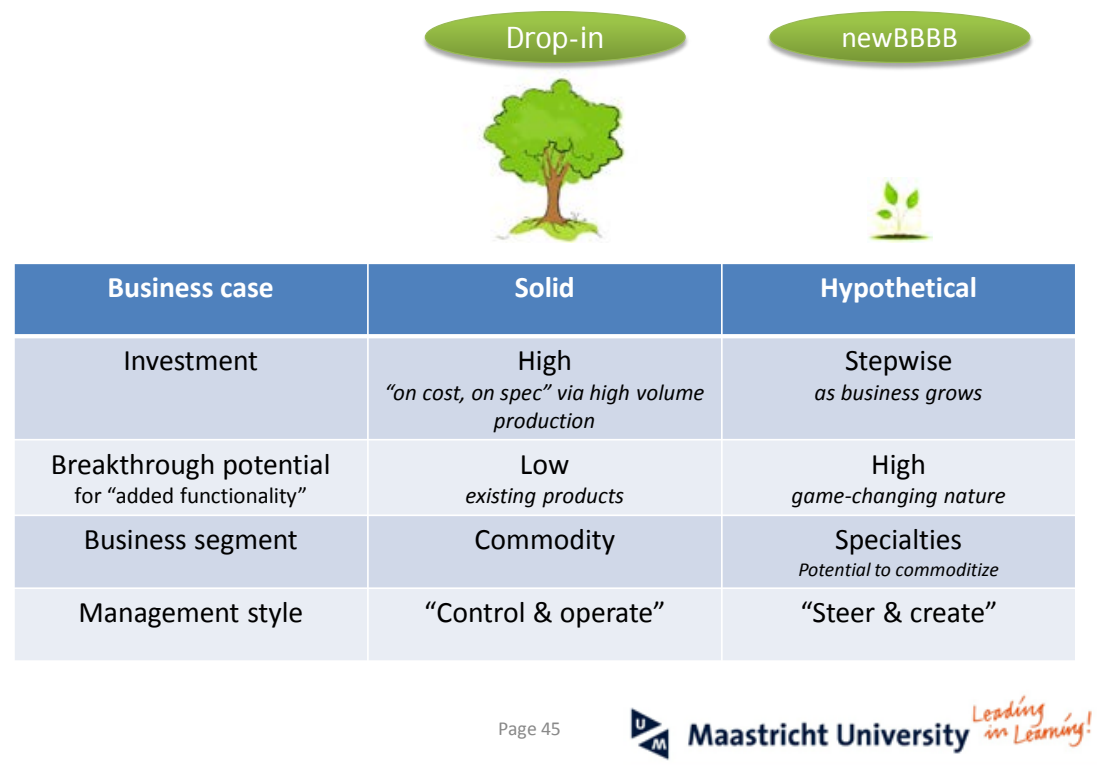

The wine and the dashboard: how ready are we for biobased products ?

\section{The Wine and the Dashboard}

- human perceptions about daily products-

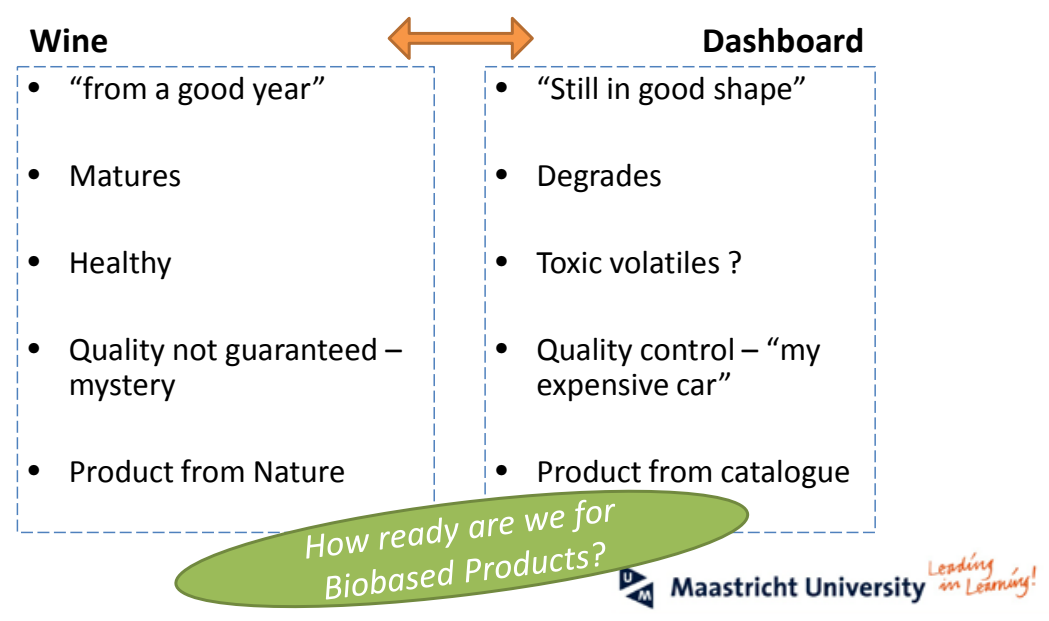


A concerted R\&D chain... creating new value chains

A concerted R\&D chain...

...creating a new value chain

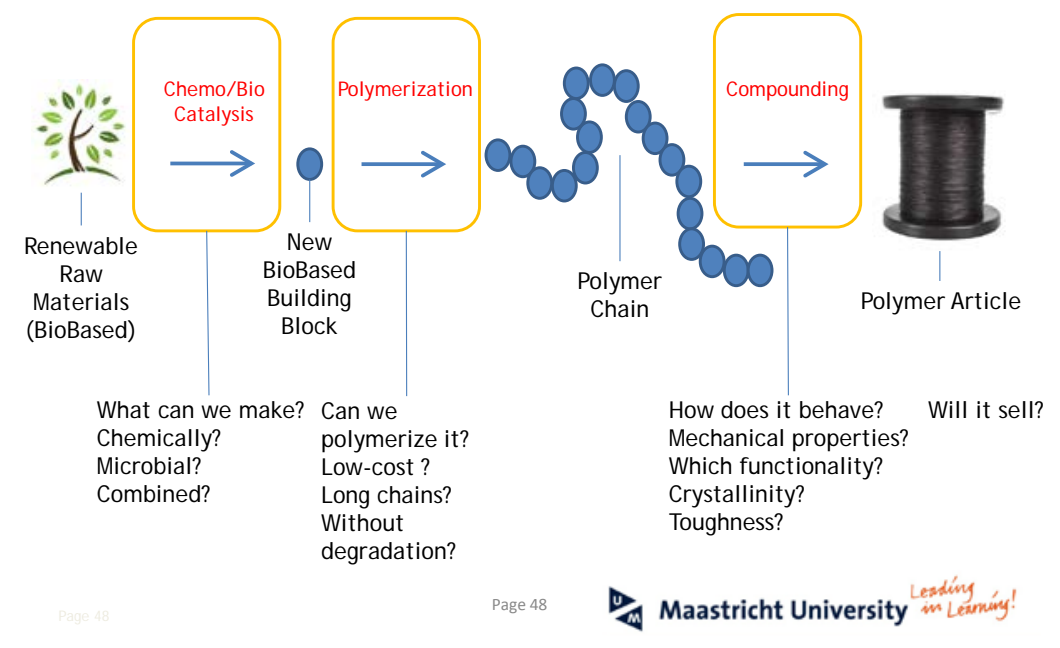

Rules of the game

\title{
Rules of the game
}

\author{
towards new BBBB's
}

1. Start low cost (cellulose, hemicellulose, vegetable oils, ,...)

2. Convert low cost, smart and exclusive

3. Rationalize/link which functionality you need for certain applications

4. Result:

combination of "blue-ocean" BBBB + unique functionality in materials

Scheme:

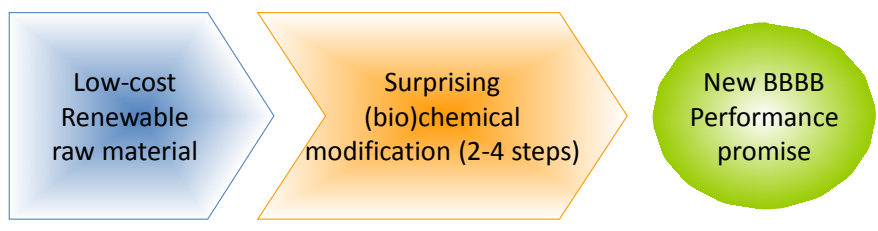

Page 49 Maastricht University in Leaningin! 


\section{From idea to proof-of-principle}

\section{From idea to proof-of-principle}

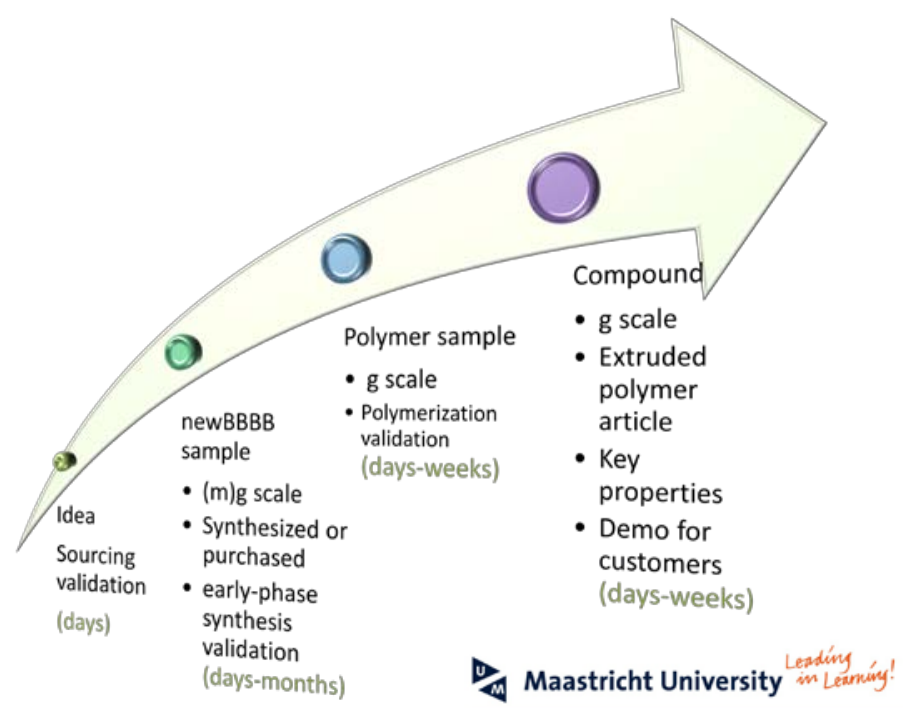




\section{Conclusie en dankwoord}

De meeste van alle mogelijke materialen, kunststoffen of kunstige stoffen die voorlopig onopgemerkt een uitstekende - zelfs logische - aansluiting kunnen vinden op hernieuwbare lokale bronnen, en die ons spectrum aan alternatieve opties dringend kunnen verbreden, moeten nog worden gemaakt en gesmaakt. Ik zou zeggen: gooi de dobbelsteen, screen je materialen, weet wat je wil, ken je wereld, en wees alert!

\section{Concluding}

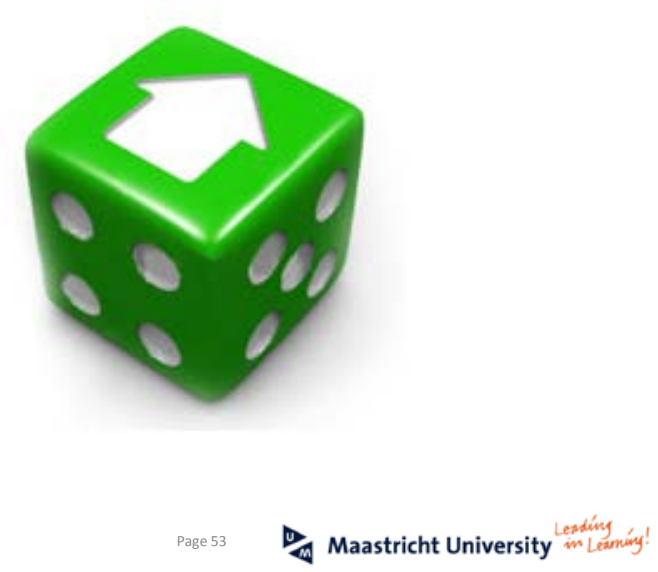

In onze jonge Biobased Materials groep op de Brightlands Chemelot Campus, huist nagenoeg een halve eeuw industriële ervaring en alertheid - op dit moment beland in een ruime plas noodzakelijke academische vrijheid. Dat alleen al toont aan hoe anders deze universiteit een technische en sociale impact wil bewerkstelligen in de bioeconomie, op deze lokale gronden vergroeid met een rijkelijk mijn-verleden - dat mij wel vaker tot nadenken aanzet: hoe deze rijkdom te continueren? Garanties in het leven zijn zeldzaam, de echte kracht zit meestal in het gebalanceerd vertrouwen en in onvoorwaardelijkheid, maar hier moeten we iets van maken. Bedankt universiteit, en collega's, dat we op deze plek en in dit tijdsgewricht, dromen durven hebben die we samen kunnen gestalte geven. Bedankt dat we in onze master Biobased Materials een nieuwe generatie studenten mogen helpen klaarstomen voor de nieuwe taken en de ongetwijfeld nieuwe waarden en normen van een biobased economy. Het danken dringt zich na veertig jaren in het leven op tot een lange rij van mensen en gewaarwordingen, 
waar ik heel veel waardering wil voor uitspreken. Op dit moment wil ik ze in 1 grote levensadem noemen, zonder de hele rij in volmaakte uitputtelijkheid af te gaan. Bedankt, voor wat ons hier bracht, en voor wat we samen nog gaan doen. Moeten doen. Want ik was nog niet klaar met mijn eindbeschouwing. Daarvoor wou ik u bij deze als gelofte van dankbaarheid graag uitnodigen.

\section{Eindbeschouwing}

Blanco slide

De plastics die we vandaag gebruiken, zijn een toevalligheid geboren uit de overvloed aan fossiele grondstoffen, die we zonder aanstoot en in de gunst der tijdsgeest midden vorige eeuw massaal zijn gaan ontginnen. Ze zijn wat ze zijn. Het geldwezen dat hen regeert kraakt af en toe in zijn voegen: de appetijt hiervoor ebt zienderogen weg binnen alle lagen van onze levens-sfeer en maatschappij. Alles draait om geld? Hmm... alles draait al miljoenen jaren langer om de zon. En de balans tussen beide dient gerespecteerd. Maar goed, de huidige plastics doen vooralsnog hun ding. En de alternatieven zijn op komst, maar worden voorlopig relatief weinig ernstig genomen. Hoezo moeten we bio-grondstoffen eerst volledig ontwateren vooraleer we er performante materialen zouden kunnen van maken? Omdat dat de regel is van onze collectie toevallige fossiele materialen die we nu kennen, infantiel qua chemie als ze zijn? De natuur heeft nooit haar volledig spectrum aan bouwstenen ontwaterd om tot de mooiste producten en vormen te komen die ik me ooit kan indenken. Weet je wat? Ik hoef niet langer jouw dashboard van poly-weet-ik-veel plastiek die wel 500 jaar meegaat, kleurvast is en krasbestendig is. Als ik aan mijn huidig fossiel dashboard denk schokt mijn neus vol met de vluchtige weekmakers die ik jaren na datum nog steeds ruik. Nee, mag ik jou eens zeggen welk dashboard ik wil? Geef mij er eentje met de touch van een perzikschil, en met de kleurschakering van een volrijpe groen-rode appel, over de hele breedte. Of beter nog, geef mij een dashboard omzwachteld door een reuzenblad van de tabaksplant, dat elke herfst verkleurt en vergeurt, en dat in de lente 
er weer fris bovenop groeit. Dan kan ik 's morgens bij de koffie zeggen ergens op een late dag in maart: mijn dashboard is vroeg dit jaar. Dát vind ik nog wel eens een dashboard. En dan hoop ik dat ik enkele opties kan kiezen, naar eigen wens: voor de sportauto kies ik voor een net rijtje haaientanden dat rond beide ventilatie-openingen groeit, enkel in de zomermaanden, als ik hem vol open zet. En bij de terreinwagen, als die straks nog bestaat, 2 middelgrote ter plaatse gegroeide olifantentanden in een boog half omlaag duikend omheen de middenconsole. Nee ze hoeven niet precies even groot te zijn. Ach, dat is een teken van de fossiele tijd. Maar wat héérlijk, dat vol ivoor in je hand, na de zware dagtaak 's avonds terwijl je door de Limburgse weide hobbelt bij zonsondergang. Het gamma aan intrigerende producten dat op deze manier mijn hoofd en mijn hart bestookt, lijkt niet te stoppen. Producten voor het jaar 2050, 2020, 2016... Aan de basis ligt soms veel, en soms weinig kennis. We zullen fantastische vindingen doen, en we zullen het soms technisch veel te moeilijk hebben gemaakt.

Naar deze wereld met dergelijke fascinerende producten wil ik vandaag toestappen. Geen geleuter over nóg sterker of nóg harder. Ik ben eerlijk gezegd plat geklopt met al je cijfers en metingen. Voor mij is sterk genoeg, sterk genoeg. Maar geef me ziel. Geef mij beleving. Zeg mij waarom. Geef mij een verhaal waarin ik wil geloven. En zeg mij, dat dit het verhaal is dat ook onze kinderen willen horen. Ik zal je eeuwig dankbaar zijn. En elke avond, voor het slapengaan, dat beloof ik jou, zal ik elk stukje kunststof in huis, stil toefluisteren: "Tot morgen".

Ik heb gezegd. 


\section{Innovation in the biobased economy: The dogma's of the fossil industry.}

Dogma 1: Do it big - or better: big enough

Projects seem too easily selected based on how big they are or could (should) become. In a world that suffers from the financial crisis and the end of hyper-capitalism, it seems difficult to be pleased with "small is beautiful" projects or companies.

Dogma 2: Do it fast - or better: fast enough

Time is money, and money determines everything. That is the credo of the old economy.

We are living so fast and are so busy with the benefits of the old economy, that we might become too late to act where it is really needed. Also, you can become slow if you think too long how to go fast.

Dogma 3: On a global scale - but local enough at first instance

An intrinsic bio-economy is most likely less global than we think. The basic principles in Nature are highly delocalized: sunshine and resources for materials and food. The homo sapiens is the only species ever on earth that ships goods and people around the globe without any limit and without understanding its own footprint for this. We have 4 billion of years proof that a delocalized society will work, but do not have any guarantee that a global society can survive in the way we are used to.

Dogma 4: With continued growth - or better: with enough growth potential Continued growth is the summit of virtuality and brutally said "seems a sickness of human brains". Nothing on the planet has an eternal continued growth without any decay as counter balance.

Dogma 5: Without risk - or better: with enough risk to make it happen

The risk-avoiding attitude in established organizations took amazing proportions in the last decade. Book-keeping and budget control and predictive planning seem more important than the basis ingredients for innovation: know-how, entrepeneurship, do-mentality, and a daily subtle balance between down-to-earth and strong, even visionary, belief.

Dogma 6: With out-performance - or with enough performance at an acceptable price Let's measure the Olympic values of human brains every 4 years in the Olympic games, but stop to outroll the "higher, faster, stronger" model on every aspect of society and materials selection. Nature has never selected species based on "even better", but rather on "good enough and fitter than the rest". The population that is fed-up with another "completely outperforming product" in terms of technical evaluation, is growing fast, because we start to understand the ecological downside of many of those products. Eco is getting more weight, milligram per milligram...

Dogma 7: Completely standardized - or with enough standardization but sufficient diversification

We install amazing test systems for standardization of products. We live in a society that is used to start complaining about the slightest deviations in products. New trends, luckily, go towards individualization and to "personal touch". But more importantly, Nature has based its survival strategy on (genetic) diversification, to enable adaptation to changing conditions. The standardization and consolidation credo of our current industrial production processes, is not in line with the basic principles that made selection of the fittest species such a successful method to develop and sustain Life on earth. 